\title{
The Effectiveness of the Use of Melafen Growth Promoter with Seed Treatment of Winter Wheat with Protectant "Polaris"
}

\author{
Igor Kuznetsov ${ }^{1}$, , Anastasia Povarnitsyna ${ }^{1}$, Marsel Akhmetzyanov ${ }^{2}$ \\ ${ }^{1}$ Department of Crop Production, Plant Breeding and Biotechnology, Faculty of Agrotechnology and Forestry Federal State Budgetary \\ Educational Institution of Higher Education, Bashkir State Agrarian University, Ufa, Russia \\ ${ }^{2}$ Department of Crop Production, Faculty of Agronomy Federal State Budgetary Educational Institution of Higher Education, Kazan State \\ Agrarian University, Ufa, Russia \\ Email address: \\ kuznecov_igor74@mail.ru (I. Kuznetsov), anastasia8020@yandex.ru (A. Povarnitsyna), marsel-praktika@mail.ru (M. Akhmetzyanov) \\ ${ }^{*}$ Corresponding author
}

\section{To cite this article:}

Igor Kuznetsov, Anastasia Povarnitsyna, Marsel Akhmetzyanov. The Effectiveness of the Use of Melafen Growth Promoter with Seed Treatment of Winter Wheat with Protectant "Polaris". American Journal of Plant Biology. Vol. 4, No. 4, 2019, pp. 105-109. doi: 10.11648/j.ajpb.20190404.18

Received: October 23, 2019; Accepted: November 9, 2019; Published: November 17, 2019

\begin{abstract}
The most important task at all stages of development of modern agriculture is to increase the yield and quality of grain. Plant growth regulators can play a big role in this. In this paper, the influence of winter wheat seed treatment with Polaris fungicide and the use of Melafen growth regulator in winter wheat crops in the conditions of the Ufa district of the Republic of Bashkortostan is considered. Treatment of seeds with fungicide Polaris in combination with preparations for crop care provided yield at the level of 41.8-61.5 centner/ha. The use of Melafen in the experiment of growth regulator in the conditions of the Ufa district of the Republic of Bashkortostan provided an increase in crop yield to 59.2-63.7 centner/ha or by $30.3-40.4 \%$, depending on the applied processing scheme. Due to the fact that the group of quality-all options correspond to the 2 group of quality or grain 3-5 class, the assessment of the quality of winter wheat grain shows that in the experiment the quality of grain of all options corresponds to the 3 commodity class.
\end{abstract}

Keywords: Winter Wheat, Protectant, Yield, Productivity, Growth Regulator

\section{Introduction}

Winter wheat (Triticum) is one of the most common crops of the globe. In our country - this is the main food culture. In its grain a lot of protein, vitamins, enzymes and other valuable substances necessary for the normal development of the human body. The protein content reaches $16 \%$, nitrogenfree extractives $63 \%$, fat and fiber $2 \%$. It is a valuable crop in the field rotation and a good precursor for a number of cropspotatoes, corn, sugar beet and others [1].

In modern market conditions, in accordance with the multilateral use of wheat and the need to meet the needs of the country, it is important to increase its yield and grain quality, the development of innovative technologies that guarantee environmentally safe products, increasing production efficiency [3]. Pesticides are widely used in European crop production to stabilize yields and reduce losses from weeds, diseases and insects Jørgensen L. N., Kudsk P., Ørum J. E. (2019). While all farmers use herbicides and fungicides in winter wheat, dairy farmers use significantly fewer insecticides and plant growth regulators in winter wheat. Farmers cultivating more than 150 hectares had a higher pesticide intensity than farmers with small farms, which was observed for both sandy and clay soil farmers [4].

An important place in the technology of cultivation of winter wheat is given to pre-sowing seed treatment $[5,6]$. Competent seed treatment increases field germination, 
especially in the early stages of sowing or return of cold weather, as one of the causes of seed death is the development of harmful microorganisms. To increase field germination and fullness of seedlings, it is necessary to observe the norms of consumption of pre-parates, as they can inhibit seedlings and cause mutational changes in seeds that will be found in the offspring [7]. Of considerable interest is the protectant Polaris-fungicidal protectant intended for presowing treatment of seeds of grain crops. Any search for increasing the yield of winter wheat is currently relevant, but in the quest to increase yields should not forget about the economic and energy efficiency [8]. Special attention should be paid to the process of forming the chemical composition of grain depending on the applied technological operations [9].

\section{Conditions, Material and Methods of Research}

Object of research. The object of research was soft winter wheat (variety Volzhskaya K).

Brief description of the variety used. Soft winter wheat (Triticum aestivum L.) Volzhskaya K. Pedigree: the Variety was derived by the method of individual selection from the population obtained from crossing the varieties of winter wheat VSGI with Kinelskaya 4 (1983). It is included in the
State register of approved for use in the territory of the Russian Federation in the North-Western (2), Central (3), Volga - Vyatka (4), Central black earth (5), middle Volga (7), Ural (9) and far Eastern (10) regions. The variety is mediumripe. The variety erythrospermum. Baking qualities are gooda grade of valuable wheat. The overall baking score is 4.1 points. Variety of intensive type, winter-hardy (3,7-4,0 points), drought-resistant (4,1 points). Susceptible to brown rust $(16 \%)$. Highly susceptible to snow mold (39\%) and ear Fusarium. Medium resistance to powdery mildew (14\%).

Seed pre-treatment was carried out fungicidal protectant Polaris and synthetic growth regulator Melafen. In the phase of seedlings-tillering and heading, depending on the variant used: G - herbicide, I - insecticide, M - Melafen, F fungicide. Treatment according to the scheme of experiment was conducted: a systemic herbicide Grenades with a norm of $25 \mathrm{~g} / \mathrm{ha}$, insecticide Imidor $60 \mathrm{ml} /$ ha fungicide the Title of Duo - $250 \mathrm{ml} / \mathrm{ha}$, a growth regulator Melaphen-5 ml/ha. Observations, surveys and analyses were conducted in accordance with conventional methods.

Field experiments (2017-2018) to study the yield and quality of winter wheat were conducted in the experimental field of the department of crop production and agriculture of the Bashkir state agrarian university, academic research center. The experiment is represented by 10 variants in 4 repetitions and has an area of $200 \mathrm{~m}^{2}$.

Table 1. Scheme experience.

\begin{tabular}{|c|c|c|c|c|}
\hline № & Seed treatment & Sowing & Phase germination-tillering & The phase of earing \\
\hline 1 & Control (C) & $\mathrm{C} 1$ & - & - \\
\hline 2 & & $\mathrm{P} 1$ & - & - \\
\hline 3 & & $\mathrm{P} 2$ & $\mathrm{G}+\mathrm{I}$ & - \\
\hline 4 & & P3 & - & $\mathrm{I}+\mathrm{F}$ \\
\hline 5 & & P4 & $\mathrm{G}+\mathrm{I}$ & $\mathrm{I}+\mathrm{F}$ \\
\hline 6 & Protectant $(\mathrm{P})$ & P5 & $\mathrm{G}+\mathrm{I}+\mathrm{M}$ & - \\
\hline 8 & & P7 & $\mathrm{G}+\mathrm{I}+\mathrm{M}$ & $\mathrm{I}+\mathrm{F}+\mathrm{M}$ \\
\hline 9 & & P8 & $\mathrm{G}+\mathrm{I}$ & $\mathrm{I}+\mathrm{F}+\mathrm{M}$ \\
\hline 10 & & P9 & - & $\mathrm{I}+\mathrm{F}+\mathrm{M}$ \\
\hline
\end{tabular}

G - herbicide, I - insecticide, M - Melafen, F - fungicide, P - protectant.

\section{Results and Discussion}

Winter wheat is a common grain crop, quite demanding to external conditions. Under the influence of negative environmental factors, with a significant deviation of meteorological and climatic conditions of the weather from the recommended, there is a mass death of shoots of this crop over large areas.

Reception of seed treatment is called strategic, since its effect is not limited to the protection of seeds from pathogens of root rot, smut. This technique allows us to provide the main and decisive factor in achieving high yields-obtaining a dense and healthy stem [10]. The density of standing plants is one of the indicators of the degree of development of plants, as well as an important factor affecting the value of the winter wheat crop. It is subject to regulation and is one of the most important factors of productivity programming [11].

In our experience, the density of standing winter wheat plants ranged from 260 to 636 pieces. stems $/ \mathrm{m}^{2}$. Variant 6 with herbicide + insecticide + Melaphene treatment in the germination-tillering phase had the highest index, exceeding the control variant by $54.7 \%$ (Figure 1). The lowest result was shown by the variant 2-260 pieces. stems $/ \mathrm{m}^{2}$, where only pre-sowing treatment with a mordant was carried out without subsequent spraying with drugs in the development phases. 


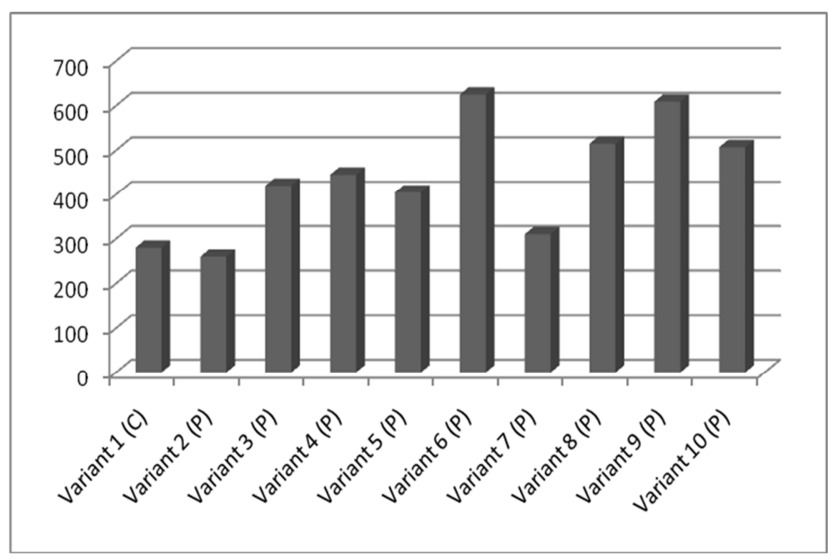

Figure 1. Standing density of winter wheat plants, pieces. stems $/ \mathrm{m}^{2}, 2018$.

Grain yield is most determined by the density of the productive stem. The density of the stem strongly reacts to changes in the level of external factors, and it reflects the conditions of formation of crops throughout the growing season.

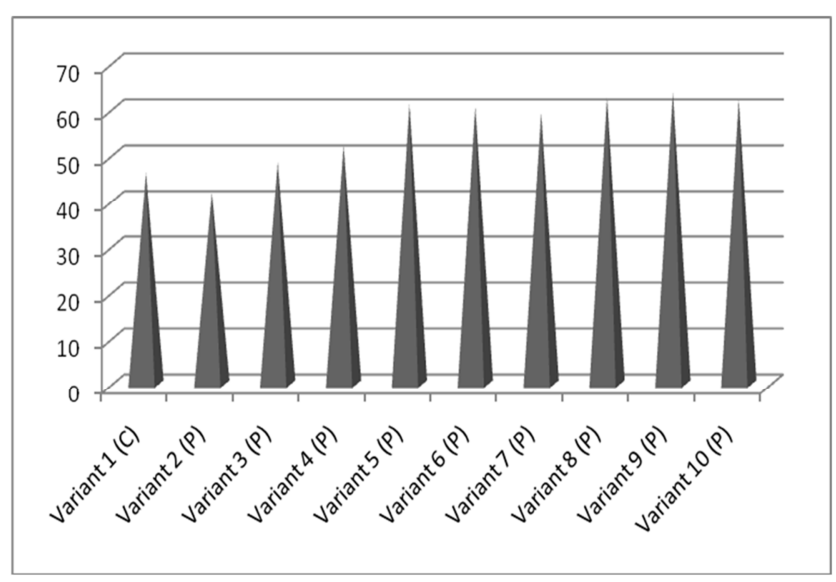

Figure 2. Winter wheat yield, centner/ha, 2018

Analyzing the data obtained, it should be noted that the yield of winter wheat grain ranged from 41.8 to 63.7 centner/ha. The use of a growth stimulant affected the increase in grain yield to 59.2-63.7 centner/ha. The highest yield of winter wheat grain was noted in variant 9, with treatment with herbicide+insecticide in the germinationtillering phase, and insecticide+fungicide+Melaphene in the earing phase, exceeding the control variant by $40.3 \%$. Good indicators had variants of experience- 8 and 10 , which formed the grain yield at the level of 62.6 and 62.1 centner/ha, respectively. The lowest result was observed in variant 2 with presowing and without subsequent treatments with a protectant -41.8 centner/ha (Figure 2 ).

One of the main problems for the grain industry at present is the problem of grain quality, which directly affects its cost. Improving the quality of wheat grain is especially important in connection with the observed trend in recent years to reduce the content of protein and gluten in it [12].

The quality of winter wheat grain is the most important component of its consumer value, competitiveness and agroecological productivity of the territory. The profit of agricultural enterprises depends on the quality of grain, as non-standard products are sold at lower prices [13].

According to GOST 9353-90, the quality indicators of winter wheat grain, which determine the class and purchase price, include the mass fraction of gluten, vitreousness, nature, and other indicators [14].

Gluten is the main component of grain, which determines the quality of baked bread. The quality of gluten is the most important factor of the baking advantages of flour, which determine the gas-holding ability of the dough, and with it the high volume and porosity of bread. GOST 52554-2006 gluten content division of grain into classes as follows: the highest class of more than $40 \%$; 1 class $32 \%$; 2 class $28 \%$; 3 class $23 \%$; 4 class $18 \%$.

As our studies have shown, the commodity quality of winter wheat grain depends on the formed indicators in 2017-2018. The mass fraction of gluten, the number of drops and the group of gluten quality (table 2).

Table 2. Quality indicators of winter wheat grain (Bashkir state agrarian university, academic research center, 2017-2018)

\begin{tabular}{lllll}
\hline № & Mass fraction of crude gluten, $\%$ & Quality of wet gluten, (units of device IDK) & Gluten quality group & Falling number, second \\
\hline 1. & 28,04 & 95,8 & II & 256 \\
2. & 31,60 & 99,8 & II & 275 \\
3. & 28,80 & 97,2 & II & 269 \\
4. & 28,56 & 97,9 & II & II \\
5. & 27,64 & 97,7 & II & 222 \\
6. & 28,32 & 96,6 & II & 277 \\
7. & 29,36 & 97,3 & II & 231 \\
8. & 26,92 & 95,8 & II & II \\
9. & 29,60 & 100,1 & 215 \\
10. & 30,80 & 97,9 & 314 \\
\hline
\end{tabular}

The analysis of table 1 shows that according to the mass fraction of crude gluten, most variants, including the control variant, have indicators characteristic of commercial grain of class 2 , but variants 5 and 8 have indicators of class 3 . In the variant with pre-sowing treatment of seeds with a mordant, without further treatments, compared with the control variant
1 without treatments, the mass fraction of crude fiber increased by $11.3 \%$. The closest to the indicator of the first class were 2 options: 2 and 10-pre-sowing treatment with Polaris mordant-11.3\% and pre-sowing treatment with Polaris $+\mathrm{I}+\mathrm{F}+\mathrm{M}$ in the earing phase $-9 \%$.

On quality of crude gluten variants of experiment had 
indicators within 95,8-100,1 IDK that corresponded to 2 group of quality or grain of 3-5 class. The best indicators were formed in 2, 4, 9 and 10 variants. According to the quality of raw gluten, the best option in the experiment was marked by 9 variant $\mathrm{P}+\mathrm{G}+\mathrm{I}$ (phase germination-tillering) + $\mathrm{I}+\mathrm{F}+\mathrm{M}$ (earing phase).

The determination of the number of drops in the experiment showed that this indicator ranged from 215-314 s., which corresponds to the indicators for the higher, first and second class of grain - Falling number more than $200 \mathrm{~s}$. The glassiness of the grain determines the consistency of the endosperm and depends on the number, composition, properties, sizes, and shape of the arrangement of starch grains and protein substances in it. Glassiness grain $60 \%$ or more is an indicator of GOST 52554-2006 for higher, 1 and 2 classes. In the experiment, the grain glassiness was $95-99 \%$ (table 3 ).

Table 3. Quality indicators of winter wheat grain (Bashkir state agrarian university, academic research center, 2017-2018).

\begin{tabular}{|c|c|c|c|c|c|c|}
\hline № п/ІІІ & Seed treatment & Phase germination-tillering & The phase of earing & Glassiness, \% & Nature of grain, g/l & Commodity class \\
\hline 1. & Control (C) & - & - & 98 & 671 & 3 \\
\hline 2. & & - & - & 96 & 708 & 3 \\
\hline 3. & & $\mathrm{G}+\mathrm{I}$ & - & 98 & 740 & 3 \\
\hline 4. & & - & $\mathrm{I}+\mathrm{F}$ & 97 & 749 & 3 \\
\hline 5. & & $\mathrm{G}+\mathrm{I}$ & $\mathrm{I}+\mathrm{F}$ & 98 & 751 & 3 \\
\hline 6. & Protectant $(\mathrm{P})$ & $\mathrm{G}+\mathrm{I}+\mathrm{M}$ & - & 95 & 752 & 3 \\
\hline 8. & & $\mathrm{G}+\mathrm{I}+\mathrm{M}$ & $\mathrm{I}+\mathrm{F}+\mathrm{M}$ & 99 & 758 & 3 \\
\hline 9. & & $\mathrm{G}+\mathrm{I}$ & $\mathrm{I}+\mathrm{F}+\mathrm{M}$ & 98 & 754 & 3 \\
\hline 10. & & - & $\mathrm{I}+\mathrm{F}+\mathrm{M}$ & 96 & 752 & 3 \\
\hline
\end{tabular}

The nature of grain is one of the most common indicators of technological properties of grain, the nature of grain is the weight of 1 liter of grain in grams, which serves as a buyer of flour and cereal evaluation. According to GOST 52554-2006 for higher, grade 1 - 2 nature of the grain should not be below $750 \mathrm{~g} / \mathrm{l}$. In the experience of the performance nature of grain had a value from 671 to $758 \mathrm{~g} / \mathrm{l}$. The application of protectant Polaris experience contributed to improving the nature of grain and a level higher, $1-2$ class of grain. The best indicators for the formation of the nature of the grain had options 9 and 8 , with the predominance of the latter.

\section{Conclusions}

Thus, the formation of yield and quality of winter wheat grain in the conditions of the Ufa district of the Republic of Bashkortostan was influenced by soil and climatic conditions of the growing season 2017-2018. Seed treatment with fungicide Polaris in combination with preparations for crop care provided yield at the level of 41.8-61.5 centner/ha.

This is consistent with the results of research by $U$. Wachowska et al. (2019). The highest content of grain protein $(14.81 \%)$ was found in plants most intensely protected with the fungicides containing fenpropimorph, pyraclostrobin and epoxiconazole. The principal component analysis revealed that the plant protection method influenced the grain protein profile [15].

Studies conducted by American scientists in Kansas B. R. Jaenisch et al. (2019) confirm the feasibility and importance of protecting winter wheat from disease. In conventional till which had high-disease pressure, the $\mathrm{Yw}$ increased grain yield by $1.2 \mathrm{Mg}$ ha-1 as compared with the FP, and foliar fungicide increased grain yield by $1.4 \mathrm{Mg}$ ha-1. Foliar fungicide and increased plant population economically reduced the YG for conventional till and notill, respectively. Net return analysis indicated that intensifying wheat management might be justifiable when using low-cost fungicides and if protein premiums are expected. Our results suggest that an integrated pest management should be preferred over an $\mathrm{Yw}$ approach with prophylactic pesticide application [16].

The use of the growth regulator Melafen in the conditions of the Ufa district of the Republic of Bashkortostan provided an increase in crop yield to 59.2-63.7 centner/ha or 30.3$40.4 \%$, depending on the applied processing schemes. Due to the fact that the group of quality-all options corresponded to group 2 quality or grain 3-5 class, the assessment of the quality of winter wheat grain shows that in the experience of grain quality of all options corresponds to 3 commodity class.

\section{References}

[1] P. I. Pravdyuk, N. N. Lysenko, «The study of the effectiveness of seed protectants against diseases in winter wheat», Russian Agricultural Science Review, 2015, Vol. 5, No. 5-1, pp. 216222.

[2] V. V. Pavlovsky et al. Application of ecosil growth regulator in spring durum wheat crops: scientific. Works// Innovations in technologies of cultivation of agricultural crops. - Minsk: Ekoperspektiva, 2009.-P. 70-73.

[3] L. N. Jørgensen, P. Kudsk, J. E. Ørum. Links between pesticide use pattern and crop production in Denmark with special reference to winter wheat// Crop Protection. Volume 119, May 2019, Pages 147-157.

[4] N. Y. Rebouh, P. M. Polityko, E. Pakina, V. G. Plushikov, A. Norezzine, A. Gadzhikurbanov, V. Vvedenskiy, F. Duksi, M. Iguer-Ouada. Impact of three integrated crop protection treatments on the varieties of winter wheat (Triticum aestivum L.) in Moscow area, Russia// Research on Crops. Volume 20, Issue 1, March 2019, Pages 161-168. 
[5] V. V. Gritsenko, D. A. Orekhov, S. Ya. Popov, «Protection of plants» Moscow: Mir, 2005, 488 p.

[6] A. G. Vlasov, Yu. A. Mirenkov, «Improvement of protective measures in spring wheat crops: monograph», Gorki: Belarusian state agricultural Academy, 2010, $136 \mathrm{p}$.

[7] N. T. Pavlyuk, G. D. Shentsev, «Influence of protectants on sowing qualities of seeds of grain crops», Bulletin of the Voronezh state agrarian university, 2016, No. 4 (51), P. 21-25.

[8] I. Yu., Kuznetsov, V. A. Bochkina, V. A. Mineeva, «Energy efficiency of single-species and mixed crops of annual fodder crops,» in Fodder production, 2014, No. 1, pp. 20-22.

[9] I. Y. Kuznetsov, B. G. Akhiyarov, I. G. Asylbaev, F. A. Davletov, V. S. Sergeev, R. R. Abdulvaleyev, A. V. Valitov, A. M. Mukhametshin, D. S. Ayupov, R. G. Yagafarov, «The effect of sudan grass on the mixed sowing chemical composition of annual forage crops», Journal of Engineering and Applied Sciences, 2018, T. 13, № 58, pp. 6558-6564.

[10] V. V. Kostyukov., Y. V. Shumilov, G. V. Volkova, «Effectiveness of protectants against root rot of Fusarium etiology of winter wheat», [Collection of articles based on the materials of the $\mathrm{X}$ all-Russian conference of young scientists dedicated to the 120th anniversary of I. S. Kosenko, 2017, pp. 344-345.]
[11] F. M. Prutskov, «Winter wheat» Moscow: Kolos, 1976, 352 p.

[12] V. I. Kargin, S. N. Nemtsev, R. A. Zakharkina, Yu. I. Kargin, «Efficiency of biopreparations in spring wheat crops», Reports of Russian Academy of agricultural science, 2011, No. 1, pp. 35-38.

[13] A. F. Melnik, A. F. Martynov, «Formation of productivity and quality of winter wheat grain» Bulletin of Orel state agrarian University, 2012, No. 2 (35), pp. 23-27.

[14] V. A. Shevchenko [et al.], «Workshop on technology of production of crop production [Electronic resource]: studies», Electron. dan. St. Petersburg: LAN, 2014. $400 \mathrm{sec}$. access Mode: https://e.lanbook.com /book/50171 - 07.08.2018.

[15] U. Wachowska, I. Konopka, A. Duba, K. Goriewa, M. Wiwart, The ef-fects of various plant protection methods on the development of Zy-moseptoria tritici and Cephalosporium gramineum, grain yield and pro-tein profile// International Journal of Pest Management. Volume 65, Is-sue 2, 3 April 2019, Pages 105-113.

[16] B. R. Jaenisch, A. de Oliveira Silva, E. DeWolf, D. A. RuizDiaz, R. P. Lollato. Plant population and fungicide economically reduced winter wheat yield gap in Kansas// Agronomy Journal. Volume 111, Issue 2, March-April 2019, Pages 650-665. 